\title{
COVID-19 og religion
}

\author{
Artikel 4 \\ HENRIK REINTOFT CHRISTENSEN, LENE KÜHLE OG BRIAN ARLY \\ JACOBSEN
}

ENGLISH ABSTRACT: Personal and societal crises often generate existential or religious questions. The article examines differences between how religiously oriented Danes think about the causes of the coronavirus and how the pandemic should be handled, compared with less religious' Danes. Unsurprisingly, the least-religious Danes are less disturbed by the extended lockdown of faith communities. Further, the article demonstrates that while a minority of Danes is very religious, those who are have a clear sense of social and religious deprivation as a result of COVID restrictions. Many in this group have participated in online community activities, but few consider these to be satisfactory alternatives to physical services. Generally, there is widespread support for the rational and scientific explanation of the virus and how it should be handled, but a minority of the most religious think the virus has divine origin and should be handled by following God's plan.

DANSK RESUMÉ: Personlige eller samfundsmæssige kriser kan give anledning til, at man stiller eksistentielle eller religiøse spørgsmål. Med afsæt $i$ en skala for religiøsitet viser artiklen, at et mindretal af respondenterne er blandt de mest religiøse, og at de naturligt forbinder nedlukningen af trossamfundene med afsavn. Til gengxld har en del af dem deltaget $i$ virtuelle alternativer. Holdningen til nedlukningen af trossamfundene adskiller sig ikke blandt de mindst og mest religiøse. Artiklen undersøger dernæst om der er forskelle blandt de religiøse og ikke-religiøse i synet på årsagen til COVID-19virusset, og hvordan man kan håndtere pandemien. Overordnet er der stor opbakning til en naturvidenskabelig forklaring på virussets oprindelse, mens et mindretal af de mest religiøse også er mere eller mindre enige $i$, at det kan have en guddommelig oprindelse. Tilsvarende er der stor enighed om, at den bedste måde at håndtere virusset er ved at følge eksperternes råd, mens et mindretal af de mest religiøse mener, man burde følge Guds plan.

KEY WORDS: COVID-19; religiosity; lockdown; deprivation; causes of COVID-19 


\section{Indledning}

Personlige eller samfundsmæssige kriser kan være anledning til, at man stiller eksistentielle eller religiøse spørgsmål. Som det har fremstået, findes der ganske forskellige forståelser af, hvorvidt COVID-19 pandemien faktisk er udgangspunktet for en krise, og i givet fald hvilken type det er (økonomisk, samfundsmæssig, eksistentiel) (jf. artikel 2, "Befolkningens reaction ..."). Men det er givet, at pandemien for nogle er blevet opfattet som en potentiel eksistentiel trussel, som kunne give anledning til en øget religiøs interesse eller engagement (jf. artikel 3, “ Undersøgelsens historiske og teoretiske baggrunde..."). Der findes allerede forskning, som peger på, at COVID19 pandemien har givet religiøse praksisser og ideer fornyet relevans. En ofte citeret undersøgelse af søgninger på søgeprogrammet Google trends foretaget i foråret viste for eksempel en markant stigning i antallet af søgninger på 'bøn', da pandemien begyndte at sprede sig (Bentzen 2020). Undersøgelser fra USA peger ligeledes på, at pandemien har medført en større religiøs interesse både i form af flere, der beder, flere der føler sig tættere på gud, og selvom der er færre, der går i kirke, er der en substantiel andel, der deltager i gudstjenester online (American Perspectives Survey 2020; Pew Research Center 2020a; 2020b). En sammenligning af svar på spørgsmålet om, hvorvidt pandemien har styrket troen, foretaget i juni-august 2020 i fjorten vestlige lande, viste, at Danmark ligger helt i bunden sammen med Sverige, Japan og Tyskland, idet kun cirka 2 procent af de adspurgte oplever en styrket tro (Pew Research Center 2021). I USA er det 28 procent af de adspurgte, der angiver, at de har fået et stærkere tro.

Undersøgelsen fra Pew bygger på et enkelt spørgsmål, hvor folk selv vurderer ændringerne i deres tro. I denne artikel vil vi i stedet undersøge spørgsmålet om, hvorvidt danskerne er blevet mere religiøse under krisen indirekte, nemlig ved at undersøge, om der er reelt er sket ændringer i svarene på ofte stillede spørgsmål om religion både i forhold til tiden inden pandemien og i løbet af pandemiens første tid. Derefter vil vi fokusere på de danskere, der ikke alene opfatter sig selv som religiøse, men som også har en - offentlig eller privat - religiøs praksis. For at kunne studere hvorvidt religiøsitet har en betydning for, hvordan folk forholder sig til pandemien, konstruerede vi en skala, som afspejler, hvad vi fortolker som udtryk for folks religiøsitet. Denne skala benyttes til at undersøge, for eksempel hvorvidt folk, der kategoriseres som religiøse, har opfattet krisen anderledes end andre. Når man i en undersøgelse inddeler folk efter religiøsitet, er det på baggrund af en antagelse om, at deres religiøsitet har betydning for den enkeltes tilværelse og (måske) for samfundet generelt. Den amerikanske religionsforsker Bruce Lincoln arbejder med et mangesidet religionsbegreb, som samlet set forstår religion som en diskurs, et sæt af handlinger, et fællesskab og en institution, som gennem relationen til en transcendent verden skaber identiteter, fællesskaber og handlings- og normregulering i denne verden (Lincoln 2002, 11-14). For nogle mennesker fylder religion så meget i deres tilværelse, at den gennemtrænger alle aspekter af social, endog af menneskelig, eksistens (Lincoln 2002, 10-11). Lincoln betegner denne form for religiøsitet som maksimalistisk. Kontrasten 
til dette er den minimalistiske position, som han hævder, at den tyske filosof Immanuel Kant (1724-1804) er eksponent for. Denne position begrænser religion til en række (primært metafysiske) anliggender og begrænser dens aktiviteter og indflydelse til denne specialiserede sfære. Religion kan i dette perspektiv anskues som placeret på et kontinuum mellem disse to idealtyper: Maksimalister, hvor religion gennemsyrer alle aspekter af livet, og minimalister, hvor religion begrænses til et vigtigt element i metafysiske spørgsmål. Maksimalister må formodes at indtænke religionen i forhold til årsagerne til pandemien, mens minimalister overlader både diagnose og løsningsforslag til videnskaben og politikerne.

Pandemien udløste en helt akut religiøs krise, da regeringer over hele verdenen beordrede religiøse grupper til at helt at lukke - eller i hvert fald kraftigt reducere deres kollektive aktiviteter. Hvordan reagerede folk, der er religiøse, på denne situation? Og er det muligt at sige noget om forskellen mellem minimalister og maksimalister i forhold til dette? Nedlukningen skete ovenikøbet i en periode, hvor de store verdensreligioner fejrede nogle af deres største højtider (jf. artikel 1, “COVID-19 krisen. Forløb og bekymringer"). På grund af den tætte relation mellem folkekirken og staten blev folkekirken meget hurtigt inddraget i forhandlinger om nedlukningen af offentlige institutioner, som statsministeren annoncerede den 11. marts. Dagen efter udsendte kirkeministeren en kraftig opfordring til trossamfund uden for folkekirken om at aflyse kollektive aktiviteter, mens deres bygninger blev pålagt at lukke for offentligheden den 4. april (Kirkeministeriet 2020a). Fra den 18. maj blev det igen muligt at åbne kirker, synagoger, moskeer samt andre lokaler benyttet til religiøse formål eller af trossamfund for offentligheden, dog med betydelige restriktioner i forhold til afstandskrav, aktiviteter som fællessang og så videre (Kirkeministeriet 2020b). Denne type nedlukninger fandt sted over hele verden; men restriktioner på religionsudøvelse i Danmark, hvor man ikke alene aflyste kollektive arrangementer, men lukkede bygningerne, også for privat brug, er blevet vurderet til at være blandt de mest omfattende i Europa (La Ferrière 2020). Nedlukning af religiøse bygninger og aktiviteter fik ikke særlig stor opmærksomhed i offentligheden (jf. artikel 2, "Befolkningens reaktion på COVID-19 set i lyset af aviser og andre medier"). Vi vil imidlertid kigge nærmere på, hvordan nedlukningen blev opfattet, og bl.a. undersøge om de personer, som opfatter sig som religiøse i særligt omfang, var modstandere af dette.

\section{Reaktioner på pandemien: Er danskerne blevet mere religiøse?}

Både danske og internationale undersøgelser beskriver generelt Danmark som et sekulariseret land (Gundelach et al 2008; Zuckerman 2010; Andersen \& Lüchau 2011; Furseth 2019). Det hører dog med til beskrivelsen af danskernes religiøsitet, at en relativ høj andel af befolkningen for eksempel i den internationale værdiundersøgelse fra 2017 angiver, at de er troende, nemlig 61 procent (Værdiundersøgelsen fra 2017). Andelen, der jævnlig går i kirke og anser religion for vigtig, er noget lavere (jf. Tabel 4.1). Spørgsmålet er, om pandemien har medført en større religiøs interesse blandt den danske befolkning, bør derfor både indbefatte spørgsmål om tro og praksis. 
Umiddelbart peger vores resultater i lidt forskellige retninger. Sammenlignet med Værdiundersøgelsen fra 2017 kunne man forledes til at tro, at pandemien har medført, at befolkningen er blevet mere sekulær. Men vi har spurgt de samme respondenter i henholdsvis maj og oktober, og resultaterne peger i retning af, at tilslutningen til en religiøs identitet vokser, men uden at dette har nogen konsekvenser for hverdagen. Således var der i maj 44 procent, der svarede ja til, at de er et troende menneske, mens der i oktober var 48 procent, som svarede positivt på dette spørgsmål. Altså en mindre stigning, mens der er et lille fald $i$ andelen, der svarer, at religion er vigtig fra 8 procent i maj til 7 procent i oktober (Tabel 4.1). Andelen af folk, der angiver, at de er overbeviste ateister, stiger ligeledes sammen med andelen, der angiver, at religion slet ikke er vigtig.

Tabel 4.1. Religiøsitet ifølge værdiundersøgelsen 2017 og maj og oktober 2020, procent.

\begin{tabular}{|c|c|c|c|}
\hline & $\begin{array}{l}\text { Denne undersø- } \\
\text { gelse maj 2020), } \\
n=1.538\end{array}$ & $\begin{array}{l}\text { Denne undersø- } \\
\text { gelse, oktober } \\
2020), n=1.538\end{array}$ & $\begin{array}{l}\text { Den Danske Værdi- } \\
\text { undersøgelse 2017, } \\
n=1.695\end{array}$ \\
\hline Jeg er et troende menneske & 44 & 48 & 61 \\
\hline Jeg er overbevist ateist & 16 & 19 & 9 \\
\hline Tror på gud eller åndelig kraft & 35 & - & 3 \\
\hline $\begin{array}{l}\text { Tror ikke på Gud, ånder, åndelige kræf- } \\
\text { ter }\end{array}$ & 32 & - & 26 \\
\hline $\begin{array}{l}\text { Går til gudstjeneste mindst en gang } \\
\text { hver måned }\end{array}$ & 7 & 7 & 9 \\
\hline Går aldrig til gudstjeneste & 74 & 51 & 32 \\
\hline Religion er meget vigtig for mig & 8 & 7 & 7 \\
\hline Religion er slet ikke vigtig for mig & 40 & 43 & 30 \\
\hline
\end{tabular}

En spørgeskemaundersøgelse foretaget af Folkekirkens Uddannelses- og Videnscenter har også undersøgt spørgsmålet om ændringer i religiøs tro og praksis. Denne undersøgelse løb fra vinter hen over foråret 2020, og kan derfor direkte sammenligne ændringer, der sker i løbet af nedlukningen i foråret 2020. Undersøgelsen konkluderer, at troen på Gud er uændret i løbet af perioden, og afviser derfor tesen om, at befolkningen som helhed er blevet mere religiøs (Folkekirkens Uddannelses- og Videnscenter 2020, 283). Vores tal støtter heller ikke, at der skulle være sket en stigning i bønsfrekvensen, og tyder endda nærmere på et fald (artikel 7, “Mellem fællessang og håndvask. Ritualer og COVID-19").

En hollandsk undersøgelse, som på samme måde som denne undersøgelse og undersøgelsen fra Folkekirkens Uddannelses- og Videnscenter anvender nogle af de standardspørgsmål, som kendes fra værdiundersøgelserne, kommer til det samme 
resultat. I spørgsmålene om religiøsitet ses der ikke nogen ændringer mellem 2017 og 2020, og det leder den hollandske forsker til at konkludere, at "apparently religiosity is unaffected by a crisis of the present magnitude" (Reeskens 2020). Måske gælder det samme i Danmark: Krisen har ikke haft en sådan karakter, at den har ledt til religiøse overvejelser? Men undersøgelsen fra Folkekirkens Uddannelses- og Videnscenter finder på samme måde som vores undersøgelse, at der er områder, hvor tilslutningen til religion øges. I modsætning til stabiliteten i svarene om tro og praksis finder undersøgelsen, at der sker betydelige ændringer blandt andet i forhold til folkekirkemedlemmernes holdning og forståelse af den rolle, man ønsker, at Folkekirken skal spille i det danske samfund (Folkekirkens Uddannelses- og Videnscenter 2020, 283).

Der kan ikke stilles spørgsmål ved, at den danske befolkning er meget sekulær; men det er vigtigt at være opmærksom på, hvordan selve undersøgelsens udførsel kan påvirke de resultater, som vi finder. Dels er de spørgsmål, vi stiller primært standardspørgsmål for eksempel fra Værdiundersøgelsen. Disse spørgsmål er velafprøvede, men ikke nødvendigvis den bedste måde at få viden om folks religiøsitet uden for de institutionelle rammer. Det er også værd at være opmærksom på, at vores undersøgelse, selvom YouGovs panel er konstrueret til at være repræsentativt for den danske befolkning generelt, synes at have en sekulær bias (se Appendix “Metoder og opmærksomhedspunkter"). Dette kan hænge sammen med at selv små forskelle i måderne, hvorpå spørgsmålene stilles - for eksempel hvilken svarmulighed der nævnes først - kan give den slags udsving i svarene. Det er vigtigt at holde disse metodiske problemstillinger for øje, når der drages konklusioner. Udsving i tallene er således ikke store nok til at konkludere, at befolkningen er blevet mindre religiøs, men det synes helt solidt at konkludere, at den danske befolkning generelt ikke har reageret på COVID-19 pandemien ved i højere grad at tro på Gud eller at opfatte religion som noget meget vigtigt. Konklusionen om, at danskerne i begrænset omfang har været optaget af religion under pandemien, understøttes af svarene på et af undersøgelsens åbne spørgsmål. Det er således kun et fåtal af de cirka 700 kommentarer til spørgsmålet om, hvilke ændringer i sociale relationer og aktiviteter, der har påvirket dem mest, der nævner religion - i en undersøgelse der handler om religion. Der er således kun en enkelt, der svarer noget med Gud ("Ingen gudstjenester og fritidsaktiviteter"), mens ordet familie nævnes over 200 gange, og venner næsten lige så ofte. Der er kun to, der nævner ordet kirke i det åbne svarfelt: En angiver, at vedkommende har savnet fællesskabet i kirken ("At man ikke kan mødes i ens kirke og møde andre mennesker"), mens en anden direkte lægger afstand. ("Den sociale distance til venner og familie. Kirken kan rende og hoppe").

Der er imidlertid en mindre gruppe (på under ti procent), der støtter udsagn (stærkt enig, enig, noget enig) som, at "Coronavirus skyldes, at guddommelige/spirituelle magter reagerer på menneskers adfærd", og "Coronavirus er led i en guddommelig plan". Det er ligeledes en mindre gruppe, der har savnet religiøse sammenkomster under nedlukningen (fem procent har savnet religiøse møder, og seks procent har savnet deltagelse i offentlige religiøse højtidsfejringer), og en mindre gruppe, som forholder sig meget kritisk til nedlukningen af religiøse institutioner. Der er også en mindre gruppe (under ti procent), som vælger at følge religiøse handlinger eller høre 
religiøse oplæg online. Da flertallet af respondenterne er forholdsvis sekulære og ikke har et særlig stærkt forhold til religion i forhold til både tro og praksis, skifter vi nu til et fokus på de respondenter, der identificerer sig selv som religiøse. En skala for religion, som er sammensat af svarene på en række spørgsmål om religion, kan belyse spørgsmålet om hvordan coronapandemien har påvirket denne gruppe.

\section{Konstruktion af et mål for traditionel religiøsitet}

Ofte anvendes flere spørgsmål til at indfange folks religiøsitet, og derefter samles disse besvarelser i en overordnet skala for religiøsitet. I denne undersøgelse har vi valgt fire spørgsmål der dækker: (1) hvor ofte folk går til gudstjenester, som indikator på det man kunne kalde kollektiv praksis, (2) hvor ofte folk beder, som indikator på individuel praksis, (3) om man opfatter sig som troende eller ateist, og 4) hvor vigtig religion er i ens liv. Det kan ikke undgås, at et sådant mål er generaliserende og ikke har blik for alle nuancer; men kombinationen af både konkrete praksisser af privat og kollektiv karakter samt værdimæssige holdninger knyttet til religion giver samlet set et bedre billede af folks religiøsitet end hvert spørgsmål for sig. Samler vi disse indikatorer til en skala for religiøsitet og deler skalaen i tregrupper, vil 62 procent af respondenterne placerer sig i den mindst religiøse gruppe, 29 procent i den mellemste gruppe og ni procent i den mest religiøse gruppe.

Figur 4.1. Oversigt over antallet af religiøse respondenter, procent.

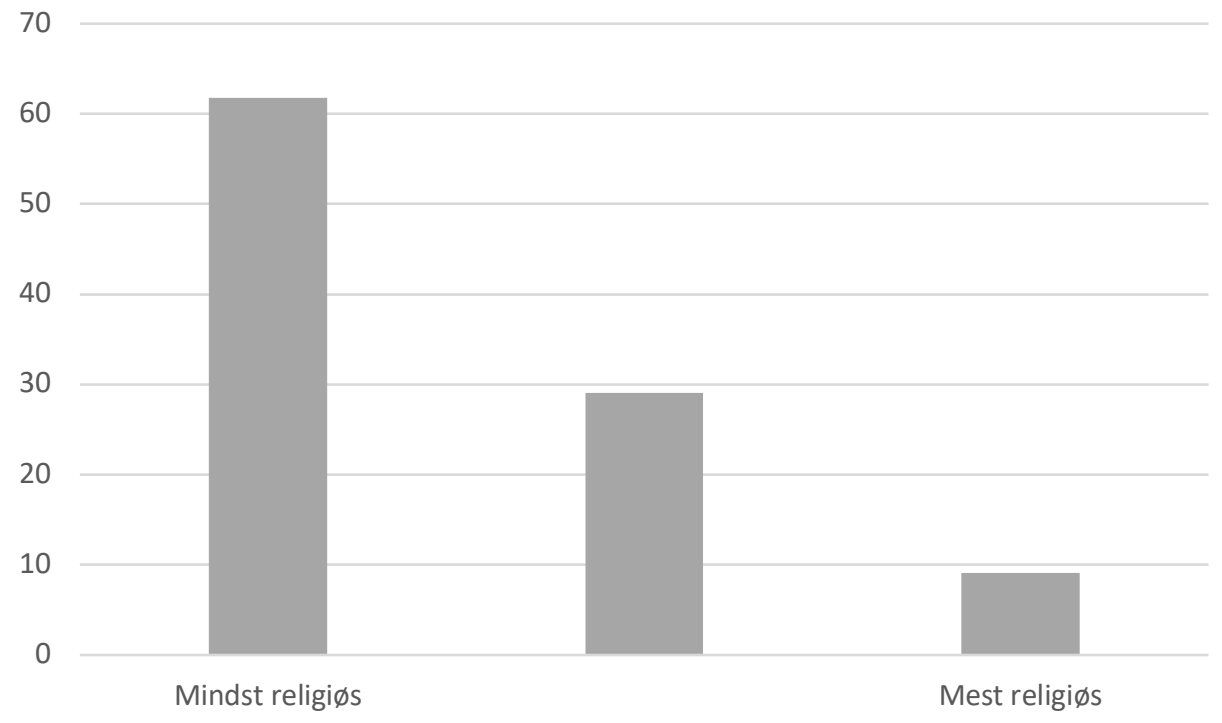

$n=1.238$

Der er også personer, som vi kan kalde spirituelle. Mennesker med individuel spiritualitet og de tilhørende individuelle ritualer, som de udfører i forbindelse med spirituelle oplevelser, har sværere ved at leve op til kriterier i en skala, som forudsætter et religiøst trossamfund og en institution. Spørgsmålet er, om individuel spiritualitet skal inkluderes i begrebet religion eller ej - det er i hvert fald religionshistorikeren 
Kocku von Stuckrads konklusion, at mange nyere former for spiritualitet udfordrer den etablerede skelnen mellem det sekulære og det religiøse (Stuckrad 2013). Da spirituelle personer i mindre grad går til gudstjenester, da de mediterer frem for at bede og føler sig spirituelle, men ikke religiøse, vil de ikke score så højt på målet for traditionel religiøsitet. Vi har derfor konstrueret en gruppe af spirituelle og inkluderet respondenter i den gruppe hvis de opfatter sig som spirituelle, men ikke går i kirke eller har en personlig gudsopfattelse. Vi har også inkluderet de respondenter, der svarer, at de opfatter sig som spirituelle, også selvom de ikke er sikre på, hvilken gudsopfattelse de har. Denne gruppe af spirituelle udgør 15 procent af de adspurgte og er dermed lidt større end gruppen af de mest religiøse, som udgør ni procent. Det er derudover værd at bemærke, at der kun er 46 respondenter (svarende til tre procent) der angiver, at de er knyttet til en anden religion end kristendom, islam og jødedom. Disse små tal gør det vanskeligt at konkludere noget i forhold til disse grupper. Resten svarer enten, at de er medlem af et kristent trossamfund (og det er primært folkekirken) eller slet ikke er religiøse, så anvendelsen af et traditionelt mål for religion og et for spirituelle er velvalgt for stort set hele gruppen af respondenter.

Da vores sample som nævnt har en tendens mod en sekulær bias, er det nødvendigt at undersøge, om denne skævhed er systematisk. Vi ved fra andre undersøgelser, at religiøsitet ofte er skævt fordelt i forhold til en række baggrundsvariable som køn, alder, og uddannelse. Inden vi undersøger religiøsitet og en række COVID-19 relaterede emner, vil vi derfor kort beskrive, hvordan religiøsitet i dette panel er fordelt på en række demografiske variable og sammenligne det med tidligere studier. I Andersen et al.'s undersøgelse af religion i værdiundersøgelsens data fra 2017 ser de også på en række af disse baggrundsvariable (Andersen et al. 2019). Derudover er det primært ældre studier af de forrige runder af værdiundersøgelserne, vi refererer til. Ser vi først på køn, viser det sig, at der er flere mænd i den mindst religiøse gruppe og flest kvinder i de to andre grupper.

Figur 4.2. Oversigt over religiøsitet fordelt på køn, procent.

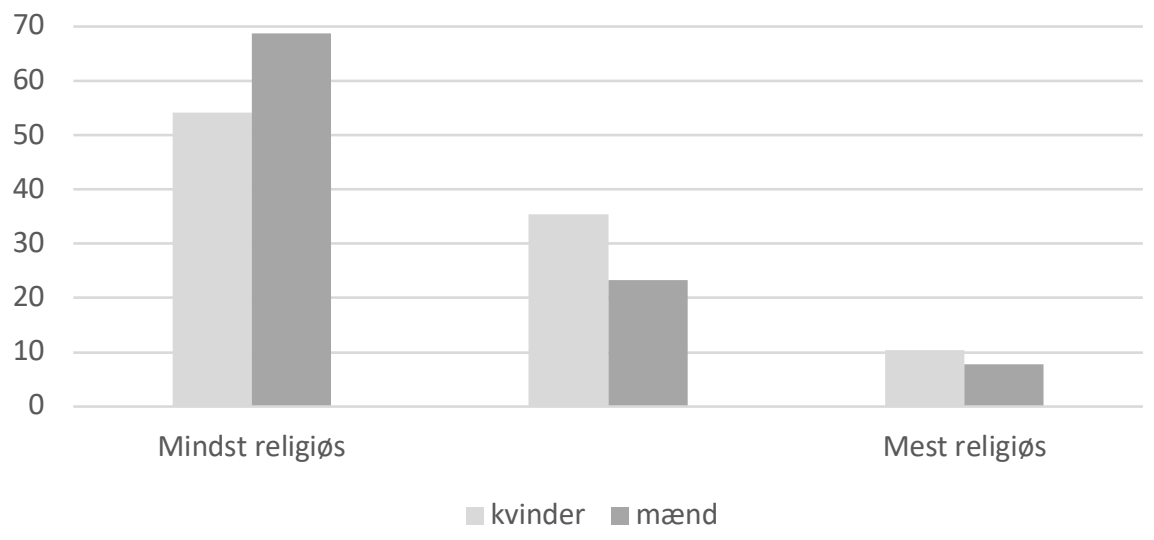

$\chi^{2}(2, n=1.238)=28,7, p<.001$

Kvinderne er generelt mere religiøse end mændene; men for den mest religiøse gruppe er forskellen mellem kønnene ikke signifikant. Den store forskel findes i de to 
andre grupper, hvor der er flest mænd i den mindst religiøse gruppe og flest kvinder i mellemgruppen. Dette er et resultat, som går igen i Andersen et al.'s undersøgelse og også i ældre undersøgelser (Halman \& Draulans 2006). If. de danske data tror flere kvinder på Gud, og flere kvinder går i kirke end mænd. For både praksis og tro er der dermed forskel på mænd og kvinder (Andersen et al. 2019, 241). Det støtter dermed op om vores skalas gyldighed.

Ser man på fordelingen i forhold til alder, er det et mere komplekst billede, fordi der er flere aldersgrupper. I nedenstående figur inddeler vi folk i tiårsintervaller med de ældste i den første kolonne. Som figur 3 viser, er der flere ting at notere sig.

Figur 4.3. Oversigt over religiøsitet fordelt på fødselsår, procent.

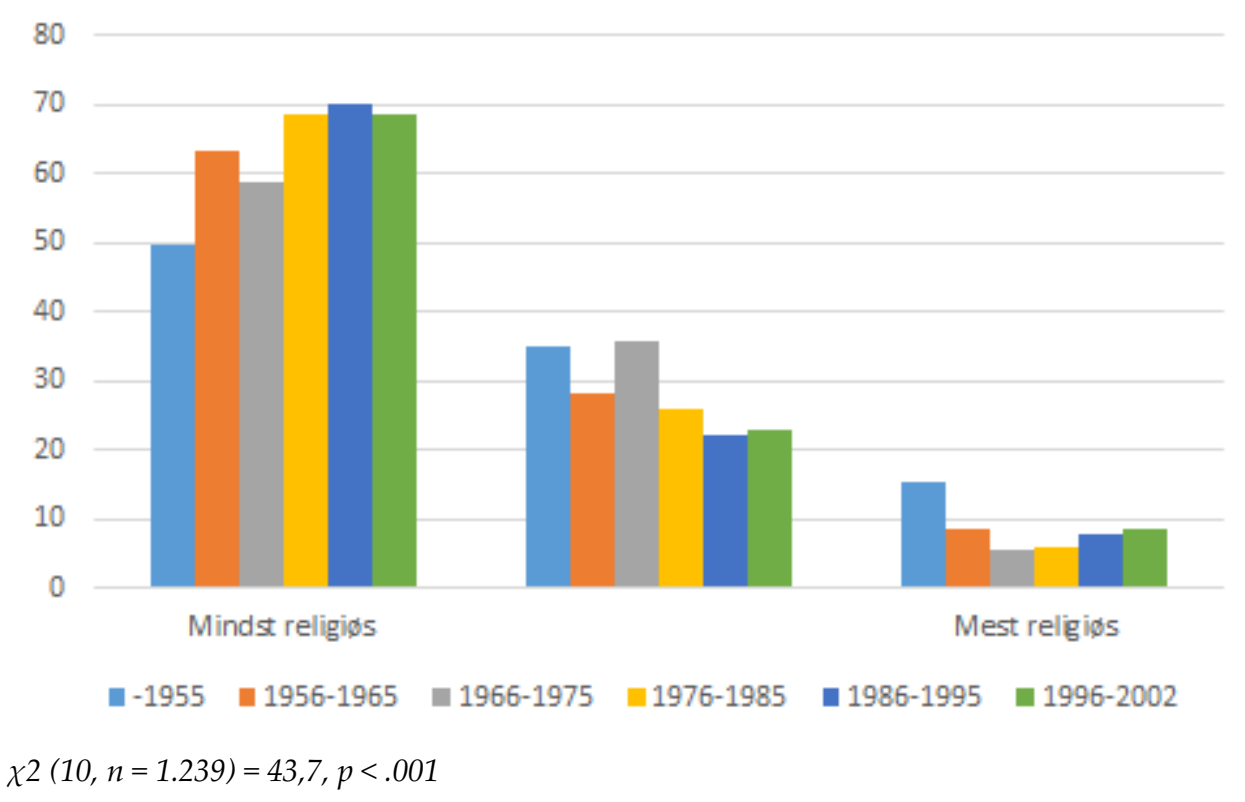

For det første er sammenhængen ikke så stærk som i forhold til køn. Den generelle tendens er dog, at jo ældre man er, jo mere religiøs er man. Blandt de yngste er der generelt flest, som placerer sig i den mindst religiøse gruppe; men der er også lidt flere i den mest religiøse gruppe end blandt de midaldrende grupper. Gruppen af 5564-årige (som er født i perioden fra midten af 1950'erne til 1960'erne) har flere, der placerer sig i den mindst religiøse gruppe end de øvrige to grupper. Dette stemmer også overens med værdiundersøgelsens tal, hvor ældre i højere grad tror på Gud og går i kirke. Disse strukturer er stabile og genfindes både i de internationale undersøgelser (Halman \& Draulans 2006) og i undersøgelser fra de tidligere runder af værdiundersøgelserne, for eksempel Peter Andersen og Peter Lüchaus undersøgelse, der viser, at kvinder og ældre har været mere religiøse over alle årene (Andersen \& Lüchau 2011, 91).

Den sidste baggrundsvariabel, vi vil undersøge, er uddannelse. Resultater fra hele den europæiske værdiundersøgelse har vist, at uddannelse ikke har en effekt på tro (Halman \& Draulans 2006, 279). Det skal dog tilføjes, at det kun gælder tros-dimensionen. For den kollektive praksis i forbindelse med kirkegang er der en svag positiv effekt (ibid., 281). Andersen et al.'s studie af den danske del af værdiundersøgelsen 
fra 2017 viser derimod, at uddannelse ikke har nogen indflydelse på hverken troen på Gud eller kirkegang (241). De finder dog en svag positiv sammenhæng mellem uddannelse og troen på reinkarnation.

Figur 4.4. Oversigt over religiøsitet fordelt på uddannelse (n=1231), procent.

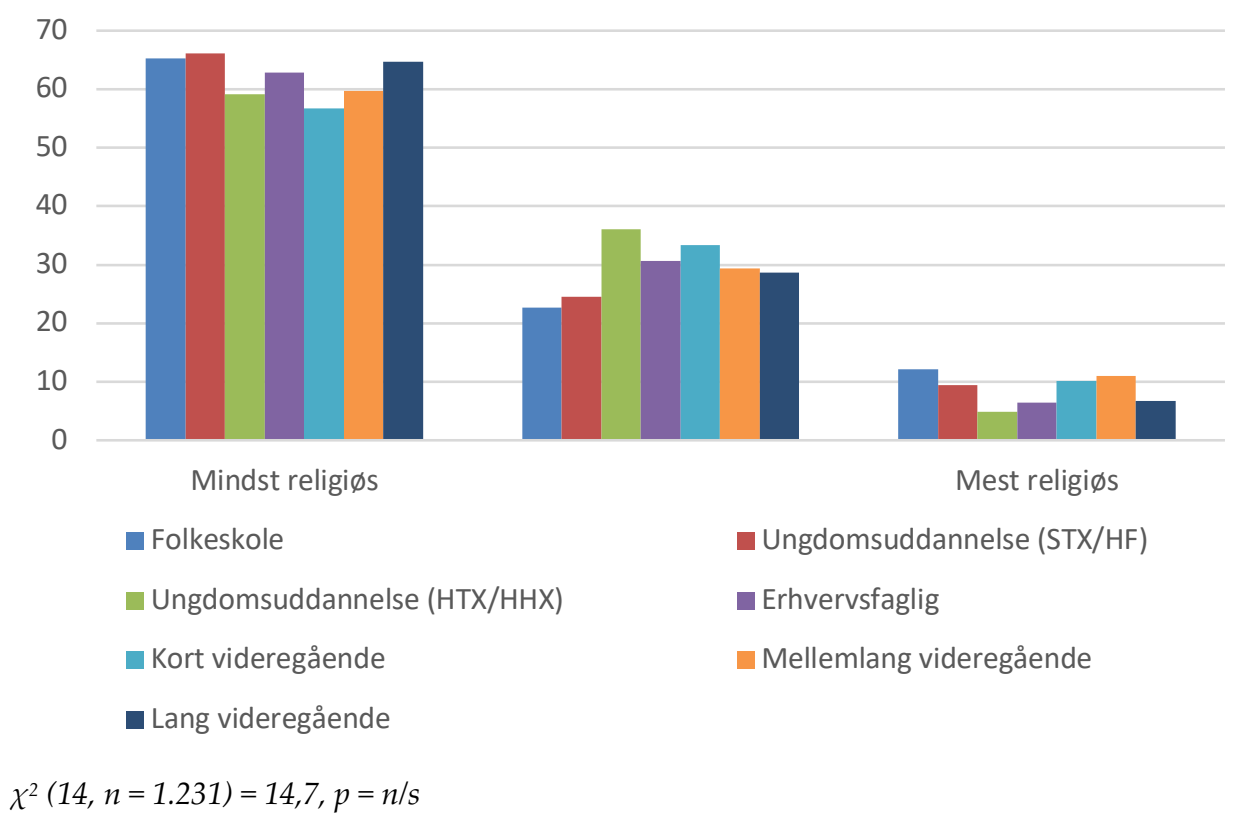

Resultaterne fra vores undersøgelse svarer til Andersen et al.'s resultater. Der er ikke nogen signifikant sammenhæng mellem religiøsitet og uddannelsesniveau. På trods af, at vores sample ser ud til at være mere sekulær end den, der bruges i værdiundersøgelsen, når vi dog frem til de samme relationer mellem religiøsitet og tre grundlæggende baggrundsvariable, og fordi vores skala dermed opfører sig som forventet, opfatter vi den som et relevant mål for religiøsitet. I det næste afsnit vil vi nu undersøge, hvordan religiøsitet relaterer sig til en række af spørgsmålene i undersøgelsen.

\section{Reaktioner på nedlukningen}

I dette afsnit vil vi undersøge reaktionerne på nedlukningen, og hvad religiøsitetsskalaen, vi har konstrueret, kan fortælle om dette. Når vi taler om reaktionerne på nedlukningen, mener vi reaktionerne på fire forskellige spørgsmål: (1) hvorvidt det var de mest religiøse, som i størst omfang angav religiøse højtider og fejringer eller religiøse møder, blandt de aktiviteter, som de har savnet under nedlukningen, (2) om det er de religiøse, der har været mest kritiske overfor nedlukningen af religiøse institutioner, (3) om de respondenter, der deltog i online gudstjenester, er de samme personer, der i deres svar på andre spørgsmål fremstår som de mest religiøse, og (4) om de respondenter, der angiver, at de er de mest religiøse, også er dem der svarer positivt på transcendente årsager og løsningsforslag i forhold til pandemien. 
Hvilke sociale aktiviteter er der flest, der har savnet

En af de mange konsekvenser af nedlukningen af samfundet var nedlukningen af den offentlige adgang til bygninger tilhørende trossamfund. Det gik ud over de daglige og ugentlige gudstjenester, bønner og ofringer; men det gik også ud over kristne og jødiske påskefejringer og moskeernes normalt meget velbesøgte taravih-bønner under ramadanen og eid-bønnen ved ramadanens afslutning. Derudover gik det ud over mange familiers konfirmationer, dåb, bryllupper og begravelser. Vi har spurgt folk, hvad de var mest ærgerlige over ved nedlukningen. Af de ni muligheder kunne de vælge tre. Det som folk har savnet suverænt mest blandt de forskellige muligheder, er de private sammenkomster. Dette er uanset graden af religiøsitet. Gruppen af de mest religiøse adskiller sig fra de to andre grupper ved, at de i mindre grad har savnet cafeer og restauranter.

Tabel 4.2. Hvilke begrænsninger er efter din mening forbundet med særlig store savn eller særlig negativ virkning (n=1237-1239), procent.

\begin{tabular}{|c|c|c|c|c|}
\hline & $\begin{array}{l}\text { Mindst re- } \\
\quad \text { ligiøse }\end{array}$ & $\begin{array}{l}\text { Mellem- } \\
\text { gruppe }\end{array}$ & $\begin{array}{l}\text { Mest reli- } \\
\text { giøse }\end{array}$ & Total \\
\hline Private sammenkomster ( $\mathrm{f} x$ familiefester) & 61 & 60 & 60 & 60 \\
\hline Cafeer og restauranter ${ }^{* *}$ & 37 & 34 & 19 & 34 \\
\hline Begravelser & 27 & 32 & 36 & 28 \\
\hline $\begin{array}{l}\text { Kulturinstitution (fx museum, biograf, biblio- } \\
\text { tek) }\end{array}$ & 26 & 23 & 24 & 24 \\
\hline Sportsarrangementer & 23 & 22 & 16 & 21 \\
\hline Kulturarrangementer ( $f x$ koncert, teater) & 22 & 20 & 15 & 20 \\
\hline Religiøse højtider (påske, ramadan) ${ }^{* * *}$ & 3 & 8 & 30 & 6 \\
\hline Religiøse møder (gudstjenester, fællesbøn) & 1 & 6 & 32 & 5 \\
\hline Politiske møder & 2 & 1 & 2 & 2 \\
\hline
\end{tabular}

${ }^{* *} p .<.01,{ }^{* * *} p .=.001$

Måden, spørgsmålet er formuleret på betyder, at familiefester også inkluderer konfirmationer, bryllupper, dåb og begravelser, også de ikke-religiøse af slagsen; men grundlæggende giver flertallet af de adspurgte ikke udtryk for at savne deltagelsen i det religiøse liv særligt meget. Ser man bort fra familiefester og begravelser og kigger på de jævnlige gudstjenester eller højtider, er der få (fem til seks procent) i den samlede stikpøve, der angiver, at det har været et særligt savn. Tager man højde for folks religiøsitet, kan vi dog se, at det har været et særligt afsavn for næsten hver tredje i den mest religiøse gruppe. Da respondenterne kun kunne vælge tre sociale sammenhænge, betyder valget af religiøse sammenhænge, at noget andet ikke kan prioriteres. 
Derfor adskiller gruppen af de mest religiøse sig også ved ikke at vælge besøg på cafeer og restauranter som et af deres savn i samme omfang som de to andre grupper. Det viser sig, at en fjerdedel af dem, der har brugt et af deres valg på at savne de religiøse højtider som påske og ramadan, også bruger et andet af deres tre valg på at savne regelmæssige sammenkomster som gudstjenester og fællesbøn. For en lille del af de mest religiøse fylder religion dermed så meget i deres liv, at de vælger at bruge to ud af deres tre prioriteringer på det. Alle uanset religiøsitet er dog fælles om at prioritere angivelse af at have savnet private sammenkomster med familie og venner allermest. Dette fund understøttes af svarene i de åbne spørgsmål, hvor netop savnet af familie og venner var de mest almindelige svar på spørgsmålet om, hvilke ændringer i sociale relationer og aktiviteter, som har oplevedes som det største savn.

\section{Online og fysiske gudstjenester}

Larsen et al. (2020) og Folkekirkens Uddannelses- og Videnscenters rapport om håndteringen af forårets nedlukning viser, at folkekirken i et vist omfang valgte at benytte muligheden for online gudstjenester under forårets nedlukning, således at der var en del online tilbud i forbindelse med påsken, mens meget få, da genåbningen nærmede sig i maj (FUV 2020: 162). Også en del af de andre trossamfund valgte at benytte internettets muligheder for at dele information og skabe religiøse fælleskaber.

På spørgsmålet om respondenterne har deltaget $\mathrm{i}$ online alternativer i deres trossamfund, svarer 83 procent, at de ikke har deltaget i online-aktiviteter, mens fem procent svarer, at de ofte har gjort det. Samlet set er der imidlertid 17 procent, som enten enkelte gange (12 procent) eller ofte (5 procent) har deltaget i gudstjenester eller andre religiøse tilbud online. Der er dog meget få af de respondenter, der kategoriseres i gruppen af mellem eller mindst religiøse, der jævnligt har benyttet mulighederne online.

Tabel 4.3. Deltagelse i religiøse onlinetilbud ( $n=1014)$, procent.

\begin{tabular}{|c|c|c|c|c|}
\hline & $\begin{array}{l}\text { Mindst } \\
\text { religiøse }\end{array}$ & Mellem-gruppen & $\begin{array}{l}\text { Mest } \\
\text { religiøse }\end{array}$ & Total \\
\hline Aldrig & 94 & 71 & 44 & 83 \\
\hline Næsten aldrig & 5 & 13 & 5 & 7 \\
\hline Sjældent & 1 & 12 & 13 & 5 \\
\hline Ofte & 0 & 4 & 39 & 5 \\
\hline $\mathrm{n}$ & 760 & 356 & 110 & 1226 \\
\hline
\end{tabular}

Respondenterne i gruppen af de mest religiøse adskiller sig således fra de to andre grupper ved, at kun 44 procent aldrig har deltaget i et online arrangement, og med 39 
procent har en markant større andel ofte deltaget i religiøse online-arrangementer. Disse svar peger på, at selv blandt de mest religiøse er der trods alt en del, der ikke har benyttet sig af online tilbud. Konklusionen er derfor, at omlægningen til onlinegudstjenester har appelleret til en gruppe ud over kernegruppen af jævnlige kirkegængere, men at det kun i begrænset omfang er lykkedes at tiltrække disse jævnligt. For de mest religiøse kan vi se, at mange både har savnet den sociale dimension af deres religiøse liv og gjort brug af de virtuelle alternativer, som altså ikke har kunnet erstatte det fysiske samvær. Religiøsitetsskalaen viser, at de mennesker, som i forvejen er mest religiøse, - ikke overraskende - er de samme personer, som har deltaget $\mathrm{i}$ online-gudstjenester. De fleste har derfor ikke savnet det sociale religiøse liv, fordi det i forvejen ikke var en del af deres hverdag.

\section{Hvad skyldes coronavirussen?}

Mediernes dækning af pandemiens første måneder placerede flere gange religion højt på dagsordenen. Medierne har blandt andet bragt flere historier om, hvordan religiøse organisationer har bidraget til smittespredningen: Kirker i Sydkorea og Alsace, religiøse lærde i Iran, muslimske missionærer i Indien. ${ }^{1}$ Er der noget, der tyder på, at religiøse mennesker har lagt ansvaret for håndteringen af pandemien i guds hænder? Er der en sammenhæng mellem religiøsitet og spørgsmål om, hvordan vi skal overkomme pandemien? Eller kan det tænkes, at folk svarer, som de plejer på spørgsmål, om deres religiøse tro og praksis, men at de alligevel tilskriver pandemien en guddommelig eller religiøs betydning? Der findes mange forklaringer, herunder konspirationsteorier om virussets opståen og udbredelse. Vi har spurgt, om respondenterne mener, at der en naturlig eller en overnaturlig forklaring på udbruddet af coronavirus, hvor vi har givet respondenterne mulighed for at vælge mellem fem forskellige overordnede fortællinger. Vi har spurgt, hvor enige eller uenige folk er i de fem årsager til coronavirussets opståen. Folk har haft mulighed for at svare på tre grader af enighed: stærkt enig, enig og noget enig, og det samme gælder uenighed. I tabellen vises både svarene fra dem, der er stærkt enige, og så det samlede svar fra alle enige. Det betyder, at 25 procent af alle respondenterne er stærkt enige i, at corona er skabt gennem en naturlig proces og kan forklares naturvidenskabeligt, og slår vi alle dem der er enige sammen, det vil sige både dem, der er stærkt enige, enige og noget enige, er 80 procent af respondenterne i en eller anden grad enige i udsagnet. Den første tabel viser svarene fra den samlede befolkning. Den efterfølgende tabel ser nærmere på svarene i de tre forskellige grupper af religiøse. Det er værd at bemærke, at i modsætning til spørgsmålet om afsavn har de ikke skullet prioritere mellem de nedenstående årsager, men skullet svare på, hvor enige eller uenige de er i forhold til hver årsagsforklaring. Det viser sig, at der er mange af de mest religiøse, der i et eller andet

\footnotetext{
${ }_{1}$ Se for eksempel følgende artikel fra videnskab.dk der dækker de forskellige lande: https://videnskab.dk/forskerzonen/kultur-samfund/coronavirus-saetter-verdens-religioner-under-pres og yderligere referencer i artikel 2, “ Befolkningens reaktion på COVID-19 ...".
} 
niveau er enige i den naturvidenskabelige forklaring, men også i et eller andet niveau er enige i de overnaturlige forklaringer.

Tabel 4.4. Årsagerne til coronavirus, procent.

\begin{tabular}{lccc}
\hline Coronavirus... & $\begin{array}{c}\text { Alle } \\
\text { enige }\end{array}$ & $\begin{array}{c}\text { Stærkt } \\
\text { enige }\end{array}$ & $n$ \\
\hline $\begin{array}{l}\text {..skyldes en tilfældighed og kan forklares naturvidenskabeligt } \\
\text { (tilfældighed) }\end{array}$ & 80 & 25 & 1252 \\
$\begin{array}{l}\text {..skyldes menneskers adfærd og kan forklares naturvidenskabe- } \\
\text { ligt (adfærd) }\end{array}$ & 86 & 33 & 1287 \\
$\begin{array}{l}\text {..skyldes, at Naturen reagerer på menneskehedens adfærd (Na- } \\
\text { turen) }\end{array}$ & 44 & 10 & 1256 \\
$\begin{array}{l}\text {...skyldes, at overnaturlige magter reagerer på menneskehedens } \\
\text { adfærd (overnaturlig) }\end{array}$ & 8 & 2 & 1378 \\
$\ldots$ er led i en guddommelig plan (guddommelig) & 8 & 1
\end{tabular}

* Stærkt enig, enig og noget enig talt sammen.

Det er tydeligt, at de fleste danskere opfatter virusset som et fænomen, der kan forklares naturvidenskabeligt. Der er også stor enighed om, at det både kan skyldes en tilfældighed eller menneskers adfærd. Der er mindre opbakning til, at det er naturens måde at reagere på menneskers adfærd på, og meget mindre opbakning til forestillingen om, at det skyldes overnaturlige magter. Hvis vi undersøger årsagerne igen, men denne gang ser på dem i forhold til, hvor religiøse folk er, kan vi, måske ikke overraskende, se, at der sker en ændring i de to overnaturlige årsager.

Tabel 4.5. Årsagerne til coronavirus i forhold til religiøsitet, procent, n=1061-1148.

\begin{tabular}{llllllll} 
& \multicolumn{2}{l}{ Mindst religiøse } & \multicolumn{2}{c}{ Mellem-gruppe } & Mest religiøse \\
Coronavirus... & $\begin{array}{l}\text { Alle } \\
\text { enige }\end{array}$ & $\begin{array}{l}\text { Stærkt } \\
\text { enige }\end{array}$ & $\begin{array}{l}\text { Alle } \\
\text { enige }\end{array}$ & $\begin{array}{l}\text { Stærkt } \\
\text { enige }\end{array}$ & $\begin{array}{l}\text { Alle } \\
\text { enige }\end{array}$ & $\begin{array}{l}\text { Stærkt } \\
\text { enige }\end{array}$ & $\gamma$ \\
\hline Tilfældighed & 83 & 29 & 77 & 18 & 80 & 26 &,$- 16^{* * *}$ \\
Adfærd & 88 & 37 & 85 & 26 & 89 & 32 &,$- 11^{* *}$ \\
Naturen & 38 & 9 & 51 & 9 & 58 & 13 &, $19^{* * *}$ \\
Overnaturlige magter & 4 & 1 & 12 & 2 & 24 & 7 &, $57^{* * *}$ \\
Guddommelig plan & 4 & 0 & 11 & 1 & 26 & 9 &, $57^{* * *}$
\end{tabular}

${ }^{* *} p .<.01,{ }^{* * *} p .=.001$ 
Selv på tværs af de religiøse grupper er der stor tilslutning til, at der er en naturvidenskabelig forklaring på coronavirussets opståen. Der er dog en svag sammenhæng at spore, der viser at de mere religiøse i mindre grad er enige i udsagnene om den naturvidenskabelige forklaring. Der er langt færre, der mener, at virusset skyldes, at Naturen reagerer på menneskehedens adfærd; men her er der en positiv sammenhæng, så de mest religiøse overordnet set er mere enige i, at Naturen reagerer på vores adfærd. Hvad angår de to sidste spørgsmål, er der ikke overraskende en stærk sammenhæng mellem religiøsitet og en overnaturlig forklaring. Holdningerne til årsagerne til pandemien afspejler en forskel mellem religiøse minimalister og maksimalister, idet maksimalister vil udstrække anvendelsen af religiøse forklaringsmodeller til områder, hvor videnskaben hævder at kunne levere forklaringsmodeller. Blandt den lille gruppe af meget religiøse er der godt nok samlet set et flertal, der tilslutter sig betydningen af naturvidenskabelige forklaringer (på henholdsvis 80 og 89 procent); men der er også 26 procent, der er enige i, at der er en transcendent forklaring på virusset (Overnaturlige magter eller Guddommelig indgriben). Blandt de mest religiøse er der dermed personer, der i et eller andet omfang er enige i både den naturvidenskabelige og den overnaturlige forklaring. Der er mindre end 10 procent af de mest religiøse, der er stærkt enige i de overnaturlige forklaringer, og da det i forvejen er en lille gruppe, er der kun henholdsvis seks og otte personer der er stærkt enige, i at der er en guddommelig forklaring. Overordnet er der selv blandt de mest religiøse en meget lille andel, der er maksimalister.

Vi har også undersøgt synet på disse årsager blandt de spirituelle, og de adskiller sig ikke fra det generelle mønster med undtagelse af, at de i mindre grad (kun 72 procent er enige) end både befolkningen generelt og de tre religiøse grupper mener virusset skyldes en tilfældighed. I forhold til de øvrige årsager placerer de sig primært mellem de to mest religiøse grupper. På baggrund af ovenstående er svarene på spørgsmålet om, hvad man kan gøre for at komme pandemien til livs, også logiske. Dem der mener, at virusset har en guddommelig årsag, mener også, at vi skal følge Guds plan for at komme den til livs. Vi har også her givet folk en række muligheder, og de har heller ikke her skullet prioritere mellem dem.

Tabel 4.6. Hvordan kommer man pandemien til livs? Enige, procent.

\begin{tabular}{|c|c|c|c|c|c|}
\hline & $\begin{array}{l}\text { Mindst reli- } \\
\text { giøse, } n=764\end{array}$ & $\begin{array}{c}\text { Mellem- } \\
\text { gruppen, } \\
n=361\end{array}$ & $\begin{array}{c}\text { Mest religi- } \\
ø s e, n=113\end{array}$ & $\begin{array}{c}\text { Spirituelle, } \\
n=226\end{array}$ & $\begin{array}{c}\text { Total, } \\
n=1538\end{array}$ \\
\hline $\begin{array}{l}\text { At følge eksperternes råd } \\
\text { og vejledning }\end{array}$ & 83 & 80 & 78 & 76 & 82 \\
\hline At vi alle ændrer vores liv & 29 & 34 & 32 & $38^{* *}$ & 31 \\
\hline $\begin{array}{l}\text { At vi alle respekterer Natu- } \\
\text { rens orden }\end{array}$ & 19 & 22 & 20 & 24 & 20 \\
\hline At vi alle følger Guds plan & 0 & 3 & $13^{* * *}$ & 2 & 2 \\
\hline
\end{tabular}


${ }^{* *} p .<.01,{ }^{* * *} p=.001$

I alt svarer 82 procent, at man skal følge eksperternes råd og vejledning, 20 procent at vi skal respektere Naturens orden, og to procent at vi skal følge Guds plan. Derudover er der 31 procent, der mener, at vi alle skal ændre vores liv, mens 5 procent ikke ved, hvad vi skal gøre for at komme virusset til livs. Der er dog signifikant flere, der svarer ved ikke i gruppen af de mest religiøse end i de to andre grupper. Derudover er det eneste andet svar, hvor de mest religiøse afviger, spørgsmålet om at det handler om at følge Guds plan. Men selv blandt de mest religiøse er der 78 procent, der mener, at løsningen er at følge eksperternes råd og vejledning. Tilslutningen til det maksimalistiske svar, nemlig at man skal følge Guds plan, er langt større blandt de mest religiøse end blandt de mindre religiøse, nemlig 13 procent (eller 15 personer), men peger også på, at der blandt de mest religiøse danskere, er det et lille mindretal, der kan beskrives som maksimalister. I forhold til de spirituelle er den eneste signifikante forskel, vi finder, den løsningsmodel, der handler om, at vi skal ændre vores liv. At de spirituelle adskiller sig fra de religiøse, ses blandt ved at den mindst signifikante løsningsmodel, er at følge Guds plan. Svarene på ovenstående spørgsmål peger på samfundet og borgerne som grundlæggende sekulariserede. Det er videnskaben og ikke religionen, der kan tilbyde en løsning på krisen.

Det er værd at bemærke, at data fra runde $1 \mathrm{blev}$ indsamlet i slutningen af maj, før de indledende genåbninger, sommerferien og den efterfølgende lange opblomstring af pandemien i store dele af landet i efteråret 2020, hvor mundbind pludselig blev krav flere steder, efter at myndighederne i startfasen havde sagt, at de ikke havde nogen effekt - tværtimod.

\section{Holdning til regeringens nedlukning af trossamfund}

Endelig er det interessant at undersøge folks holdning til nedlukningen af trossamfundene i og med, at det ikke er forekommet siden grundlovens indførelse. Overordnet set støtter 88 procent af de adspurgte regeringens nedlukning af trossamfundene. Ser man igen på de tre religiøse grupper, så er der kun lidt forskel mellem dem, som figuren viser. 
Tabel 4.7. Holdningen til nedlukningen af trossamfund $(n=1.158)$, procent.

\begin{tabular}{lcccc} 
& $\begin{array}{c}\text { Mindst religi- } \\
\text { øse }\end{array}$ & $\begin{array}{c}\text { mellem- } \\
\text { gruppe }\end{array}$ & Mest religiøse & Total \\
\hline Stærkt uenig & 4 & 4 & 4 & 4 \\
Uenig & 2 & 3 & 6 & 3 \\
Noget uenig & 4 & 9 & 6 & 8 \\
Noget enig & 6 & 11 & 11 & 31 \\
Enig & 28 & 34 & 34 & 50 \\
Stærkt enig & 57 & 39 & 39 &
\end{tabular}

Blandt de to mest religiøse grupper støtter 84 procent nedlukningen, mens støtten blandt de mindst religiøse er 90 procent. Der er dermed en ikke stor, men alligevel signifikant forskel på grupperne. De mest religiøse er i mindre grad enig i nedlukningen. Vi så ovenfor, at 30 procent af de mest religiøse giver udtryk for at savne det sociale aspekt af det religiøse liv (Tabel 4.2.), men helt overordnet støtter de op om nedlukningen af trossamfundene. Udover at støtten til nedlukningen afhænger af religiøsitet er det også muligt den afhænger af politisk ståsted. Da vi har mange politiske partier, er de her reduceret til de to blokke, der udgøres af den typiske opdeling i henholdsvis blå og rød blok. Der er spurgt til både respondenternes faktiske valg ved seneste folketingsvalg og så, hvad man ville vælge, hvis der var valg i dag (i maj 2020). Vi har valgt at se på deres faktiske valg ved sidste valg. Til rød blok har vi samlet Enhedslisten, SF, Socialdemokratiet, Radikale Venstre og Alternativet, mens blå blok består af Venstre, Konservative, Dansk Folkeparti, Liberal Alliance og Nye Borgerlige. De partier, der ikke kom over spærregrænsen ved valget (Kristendemokraterne, Klaus Riskær Pedersen og Stram Kurs), er alle inkluderet i blå blok. Derudover er der en række respondenter, der ikke havde stemmeret, ikke stemte, eller ikke vil svare. Inden vi ser nærmere på holdningen til nedlukningen i forhold til, hvilken politisk blok man tilhører, er det relevant at undersøge, hvordan de er fordelt på religiøsitet. 
Figur 4.5. Religiøsitet fordelt på to politiske blokke ( $n=1086)$, procent.

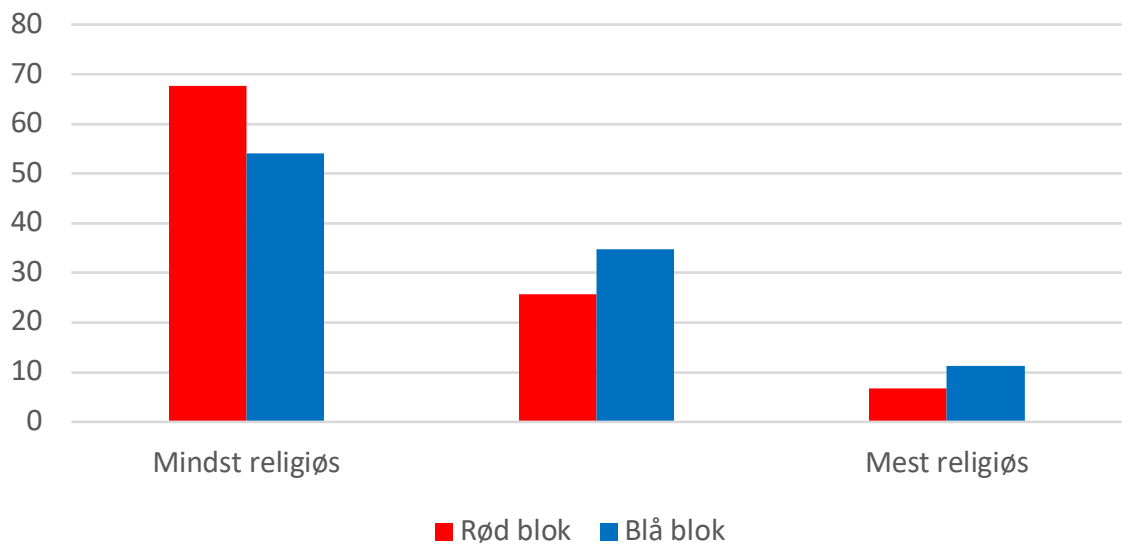

$\chi 2(2, n=1.086)=21,7, p<.001$

Figuren viser, at de vælgere, der har stemt på partier fra blå blok, generelt har en højere religiøsitet, end de vælgere der har stemt på partierne i rød blok. Også når vi kigger på hver af de tre grupper, er der signifikant forskel. Blandt de mindst religiøse er der signifikant flere, der stemmer på partier i rød blok, og i mellemgruppen og blandt de mest religiøse er der signifikant flere, der stemmer på partier i blå blok.

Hvis vi dernæst kigger på sammenhængen mellem modstanden mod nedlukningen af religiøse institutioner og politisk holdning, så fremstår der et klart mønster (Jf. Figur 4.6). Der er ikke kun tale om en specifik religiøs modstand mod nedlukningen, den er også politisk motiveret (se også Kühle og Jacobsen 2020).

Figur 4.6. Enig/uenig i nedlukningen af trossamfundenes mulighed for at forsamles fordelt på hhv. rød og blå blok ( $\mathrm{n}=1229)$.

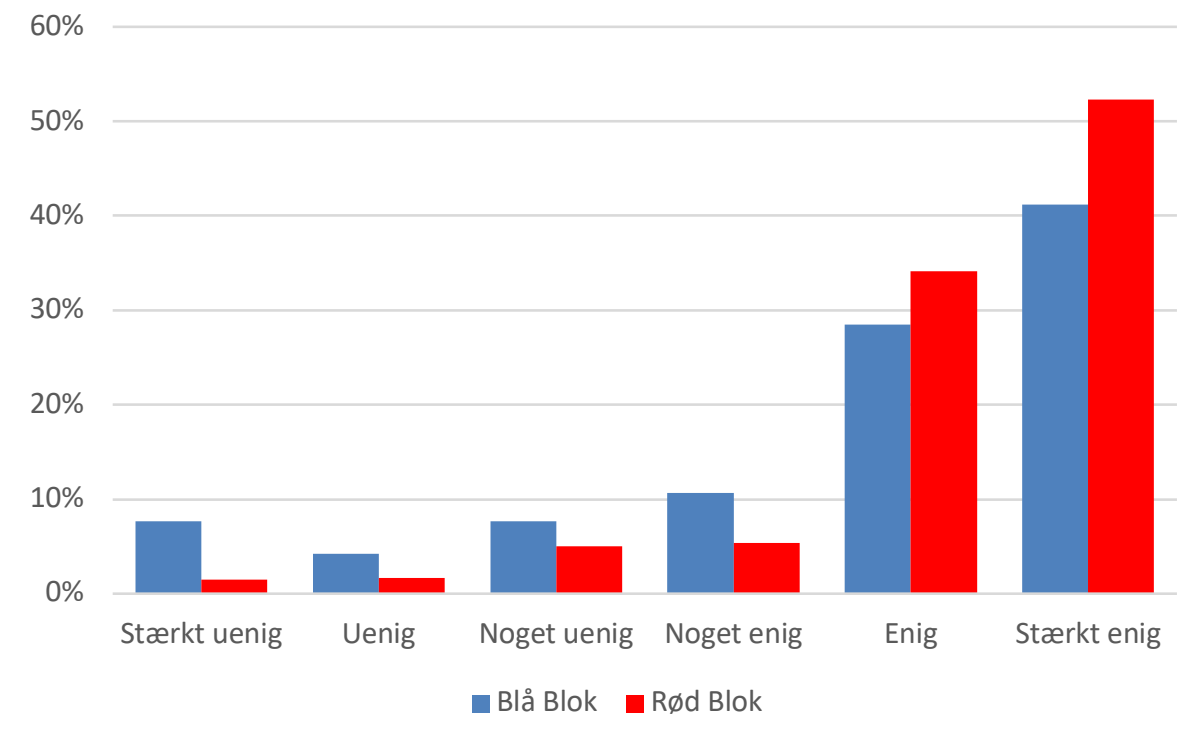

$\chi^{2}(5, n=1.229)=62,9, p<.001$ 


\section{Diskussion}

De to religionssociologer Detlef Pollack og Gergely Rosta skelner i bogen Religion and Modernity mellem to former for religion: kirkelig og ikke-kirkelig religiøsitet. Den kirkelige religiøsitet måles som medlemskab, kirkegang og tro på Gud samt, at man mener, at Gud er vigtig. En lille del af dem, vi finder i denne gruppe, kan forstås ved hjælp af Lincolns begreb om maksimalisterne - de personer hvor religionen leverer en fortolkningsramme for hele deres tilværelse og ikke kun ser religion som et anliggende der kun har betydning for metafysiske. I vores materiale er der ganske få personer, som scorer højt på vores religiøsitetsskala og som ser en guddommelig årsag til virusset samt mener at den skal håndteres ved at følge Guds plan. Den ikke-kirkelige religiøsitet måles som tro på reinkarnation og amuletter, opfattelse af, at man er spirituel, men med manglende kirkegang, og at man ikke synes gud er vigtig. Cirka 15 procent af vores respondenter ligger i denne kategori. Pollack og Rosta finder, at den ikke-kirkelige religiøsitet har meget begrænset betydning for holdninger til kønsroller, religiøse lederes politiske indflydelse og 'den offentlige moral', dvs. holdninger til skattesnyd, korruption, skatteunddragelse og brug af offentlig transport uden billet. Som vi skriver i artikel 8, "Tillid til andre og den sekulære velfærdsstat", er der dog undersøgelser, der kæder spiritualitet, brugere af naturmedicin og alternativ behandling sammen med vaccinationsmodstanden. Svar fra en undersøgelse fra 20162017 viste, at der i forhold til den almene befolkning, var signifikant flere blandt vaccinemodstanderne, der var meget enige $\mathrm{i}$, at de er åndelige mennesker, at der findes en åndelig kraft uden for det enkelte menneske, og at man kan blive rask gennem healing, krystalterapi og andre alternative metoder (Rusmann 2017). Vaccinekritikerne kræver ansvar for og selvbestemmelse over egen krop og sundhed, og engagerer sig i sundhedspolitiske debatter om vacciner og andre medicinske spørgsmål. Det har vi også set under pandemien. Den kirkelige religiøsitet derimod har en vis, men ikke særlig stor betydning for holdningerne til disse spørgsmål. Pollack og Rosta finder, at den kirkelige religiøsitet især har betydning i forhold til, hvad de betegner som 'morality of the body', dvs. spørgsmål som utroskab, abort, skilsmisse, aktiv dødshjælp og uforpligtende sex. Pollack og Rostas resultater synes at afspejle resultaterne i denne artikel godt. Flertallet af respondenterne, ca. 62 procent, placerer sig i den mindst religiøse gruppe. De går sjældent eller aldrig til gudstjenester, de beder sjældent eller aldrig, og de opfatter sig ikke som troende og anser ikke religion som en vigtig del af deres liv. Det er måske derfor heller ikke så overraskende, at personer i denne gruppe ikke har savnet religion under forårets nedlukning, ikke har deltaget i online gudstjenester og ikke er tilbøjelige til at tilskrive gud en rolle hverken i årsagen eller løsningen på pandemien. Over for dem står de cirka ni procent, som tilhører den mest religiøse gruppe. Der er mange i denne gruppe, der har savnet religion, og en del har også deltaget i online gudstjenester og lignende. Der er flere i denne gruppe end i de to andre, der tilskriver virusset en overnaturlig årsag og en del af Guds plan, men der er dog også en helt overvejende tilslutning til naturvidenskabelige tilgange. Det er faktisk i mellemgruppen af religiøse, at der er den mindste tilslutning til na- 
turvidenskabelige teorier, da kun 18 procent er stærkt enige i betydningen af naturvidenskabelige forklaringer, hvor dette er henholdsvis 29 procent og 26 procent hos de mindst og de mest religiøse. Interessant nok har religiøst engagement ingen betydning i forhold til holdningen til nedlukningen, som vurderes som et politisk spørgsmål, som religion ikke spiller ind i forhold til. Pollack og Rostas pointe er, at stærkt religiøst engagement i modsætning til, hvad mange tror, sjældent har betydning udover det religiøse felt. Med Lincolns begreb om minimalister og maksimalister kan det pointeres, at vores resultater, på linje med Pollack og Rostas store undersøgelse, understøtter en forståelse af, at også blandt dem, der kan kategoriseres som meget religiøse, er det et mindretal, som er maksimalister. Uanset religiøst engagement støtter de fleste danskere op om en sekulær forståelse af pandemiens opståen såvel som, hvordan man bør reagere.

\section{Konklusion}

I denne artikel behandlede vi spørgsmålet om, hvorvidt pandemien har medført religiøse forandringer. Det er ikke - med de svar, som vi har indsamlet - muligt at pege på sådanne. Svarene på standardspørgsmål om tro og religiøs praksis ligner dem vi kender fra lignende studier: Danskerne er i overvældende grad sekulære. Der er en lille del af befolkningen (ca. 10 procent), som kan kategoriseres som meget religiøse. Men deres svar afviger i mange tilfælde slet ikke fra resten af befolkningens svar. Det er for eksempel symptomatisk, at selvom en del af de mest religiøse har savnet religiøse aktiviteter under nedlukningen, så adskiller de sig ikke fra resten af befolkningen i forhold til holdningen til nedlukningen af religiøse bygninger. Kritikken af denne skyldes politiske holdninger frem for religiøse (jf Kühle og Jacobsen 2020). Det er kun en meget lille del af den danske befolkning, der kan beskrives som religiøse maksimalister, det vil sige folk som forbinder pandemiens opståen eller løsning med noget guddommeligt. Til gengæld er der en betydelig del af befolkningen, som mener, at pandemien måske bør lede til større overvejelser om, hvordan vi behandler hinanden og planeten, idet pandemien ses som forårsaget af menneskelig adfærd.

\section{LITTERATUR}

Andersen, Peter. Jakob Erkmen \& Peter Gundelach

2019 “Udviklingen i (ikke)religiøsitet”, in: Morten Frederiksen, ed., Usikker modernitet. Danskernes værdier fra 1981 til 2017, Hans Reitzels Forlag, 231-264.

Andersen, Peter \& Peter Lüchau

2011 "Individualisering og aftraditionalisering af danskernes religiøse værdier" in: Peter Gundelach, ed., Små og store forandringer. Danskernes værdier siden 1981, Hans Reitzels Forlag, 76-94.

Bentzen, Jeanet Sinding

2020 "In crisis we pray: Religiosity and the COVID-19 Pandemic", working paper (set december 2020), Folkekirkens Uddannelses- og Videnscenter.

2020 “Når folkekirken skal spille efter reglerne - men uden for banen", in: Folkekirkens håndtering af coronaperioden i foråret 2020 (set december 2020). 
Furseth, Inger

2019 Religious Complexity in the Public Sphere: Comparing Nordic Countries, Palgrave Macmillian. https://doi.org/10.1007/978-3-319-55678-9

Gundelach, Peter \& Hans Raun Iversen, Margit Warburg

2008 I hjertet af Danmark: Institutioner og mentaliteter, Hans Reitzels Forlag

Kirkeministeriet

2020a "Kirkeminister med kraftig opfordring til trossamfund", pressemeddelelse 12. marts 2020, https://www.km.dk/aktuelt/singlevisning/kirkeminister-med-kraftig-opfordring-tiltrossamfund (set 11. februar 2021).

2020 b "Retningslinjer for en ansvarlig genåbning af folkekirken og andre trossamfund", pressemeddelelse 17. maj 2020, https://www.km.dk/aktuelt/singlevisning/retningslinjer-for-enansvarlig-genaabning-af-folkekirken-og-andre-trossamfund (set 11. februar 2021).

Kühle, Lene \& Brian Arly Jacobsen

2020 “Corona. Sundhedsvæsenet er danskernes nye religion", Politiken, 16.08.2020.

La Ferrière, Alexis Artaud de

2020 "Coronavirus: how new restrictions on religious liberty vary across Europe", The Conversation UK (set december 2021).

Larsen, Tina Langholm, Anne Lundahl Mauritsen, Lene Kühle, Jørn Borup \& Marianne Qvortrup Fibiger.

2020 "Vi har lukket ned for alle aktiviteter", Håndteringen af COVID-19-krisen hos anerkendte trossamfund i Danmark, Center for Samtidsreligion, Aarhus Universitet. https://samtidsreligion.au.dk/fileadmin/Samtidsreligion/Trossamfund_under_Coronakrisen/Art ikel_26.05.2020.pdf

Lincoln, Bruce

2002 “Den 11. september fra en religionshistorisk synsvinkel”, Chaos 38, 7-24.

Pew Research Institute

2020a Most Americans say coronavirus outbreak has impacted their lives,

Pew Research Institute Americans Oppose Religious Exemptions From Coronavirus-Related Restrictions, https://www.pewresearch.org/global/2020/08/27/most-approve-of-nationalresponse-to-covid-19-in-14-advanced-economies/pg_2020-08-27_global-coronavirus_0-01/ (set december 2021).

2020 b "Most approve of national response to COVID-19" https://www.pewresearch.org/global/2020/08/27/most-approve-of-national-responseto- COVID-19-in-14-advanced-economies/pg_2020-08-27_global-coronavirus_0-01/ (set december 2021)

2021 "More Americans Than People in Other Advanced Economies Say COVID-19 Has Strengthened Religious Faith", https:/www.pewforum.org/2021/01/27/more-americans-than-people-in-otheradvanced-economies-say-COVID-19-has-strengthened-religious-faith/ (set februar 2021).

Pollack, Detlef, and Gergely Rosta

2017 Religion and modernity: An international comparison, Oxford University Press. https://doi.org/10.1093/oso/9780198801665.001.0001 (set februar 2021).

Reeskens, Tim, et al.

2020 "Stability or change of public opinion and values during the coronavirus crisis? Exploring Dutch longitudinal panel data", European Societies, 1-19. https://doi.org/10.1080/14616696.2020.1821075 (set februar 2021).

Rusmann, Anna

2017 Sundhed, sikkerhed og spiritualitet. Et flermetodisk studie af trosforestillinger blandt vaccinationsmodstandere, Kandidatspeciale, Københavns Universitet.

Stuckrad, Kocku von

2013 “Secular Religion: A Discourse-historical Approach to Religion in Contemporary Western 
Europe", Journal of Contemporary Religion 28 (1), 1-14.

https://doi.org/10.1080/13537903.2013.750828

Zuckerman, Phil

2010 Society without God: What the Least Religious Nations Can Tell Us About Contentment, New York University Press.

American Perspectives Survey

2020 Fear, frustration, and faith: Americans respond to the coronavirus outbreak, https://www.aei.org/research-products/report/fear-frustration-and-faith-americans-respond-tothe-coronavirus-outbreak/ (set februar 2021).

Henrik Reintoft Christensen, lektor, ph.d. Afdeling for religionsvidenskab, Aarhus Universitet

Lene Kühle, professor mso, ph.d. Afdeling for religionsvidenskab, Aarhus Universitet

Brian Arly Jacobsen, lektor, ph.d. Religionsvidenskab, Københavns Universitet 